University of Massachusetts Amherst

ScholarWorks@UMass Amherst

Economics Department Faculty Publications

Series

Economics

2021

\title{
City Limits: What Do Local-Area Minimum Wages Do?
}

Arindrajit Dube

University of Massachusetts Amherst

Attila Lindner

University College London

Follow this and additional works at: https://scholarworks.umass.edu/econ_faculty_pubs

\section{Recommended Citation}

Dube, Arindrajit and Lindner, Attila, "City Limits: What Do Local-Area Minimum Wages Do?" (2021). Journal of Economic Perspectives. 347.

https://doi.org/10.1257/jep.35.1.27

This Article is brought to you for free and open access by the Economics at ScholarWorks@UMass Amherst. It has been accepted for inclusion in Economics Department Faculty Publications Series by an authorized administrator of ScholarWorks@UMass Amherst. For more information, please contact scholarworks@library.umass.edu. 


\title{
City Limits: What Do Local-Area Minimum Wages Do?
}

\author{
Arindrajit Dube and Attila Lindner
}

$\mathbf{T}$

o date, 42 cities in the United States have instituted minimum wages above the state or federal level. Of these cities, 22 have a minimum wage that is $\$ 15$ per hour or more-including San Francisco, Seattle, Los Angeles, and Washington, DC-a level that seemed unthinkable just a few years ago. Moreover, advocates for city-wide minimum wages have played an important role both by changing wages in some of the largest and most dense labor markets in the United States and by reshaping the policy terrain more broadly. In these campaigns, advocates for a higher minimum wage first shifted their focus from state and federal government to city councils, mayors, and voters (via ballot initiatives). Subsequently, legislatures in states like California and Washington responded to city-wide minimum wages by passing large state-wide increases of their own. In contrast, other state legislatures passed laws preempting a city-wide minimum wage mandate.

The growing number of cities with minimum wages naturally raises the question: is local variation in minimum wage policies a good idea? Most of the extensive

- Arindrajit Dube is Professor of Economics, University of Massachusetts Amherst, Amherst, Massachusetts. He is also a Research Associate, National Bureau of Economic Research, Cambridge, Massachusetts, and a Research Fellow, IZA Institute of Labor Economics, Bonn, Germany. Attila Lindner is Assistant Professor, University College London, London, United Kingdom. He is also an Associate, Center for Economic Performance, London School of Economics and Research Associate, Institute for Fiscal Studies, both in London, United Kingdom; Research Affiliate, IZA Institute of Labor Economics, Bonn, Germany; and Research Fellow, Institute of Economics, Hungarian Academy of Sciences, Budapest, Hungary.Their email addresses are adube@umass.edu and a.lindner@ucl.ac.uk.

For supplementary materials such as appendices, datasets, and author disclosure statements, see the article page at https://doi.org/10.1257/jep.35.1.27. 
minimum wage literature to date has focused on state- or federal-level changes, but city-level minimum wage changes can have potentially different implications than changes that affect a state or the whole country. For instance, city boundaries are porous, and for many businesses it might be easy to relocate to a few miles outside of the city boundaries. This distortion may also be present to some extent for statelevel minimum wages, but it could be much larger for minimum wage changes that are restricted to cities. On the other hand, local variation in minimum wages can better tailor the policy to local circumstances. For example, the level of minimum wage that might raise concerns about unintended consequences in rural areas in California may not bind at all in San Francisco or Los Angeles, given the generally higher wages in those cities.

To evaluate these trade-offs, we begin with some descriptive evidence on the evolution of city-level minimum wage policies. We examine what type of cities have instituted minimum wages and discuss how these characteristics can potentially impact the effectiveness of city-level minimum wage policies. In the next part of the paper, we summarize the evolving evidence on city-level minimum wage changes and provide some new evidence of our own. By combining the existing evidence from cities with some additional insights obtained from the literature on stateand federal-level changes, we provide an overall (if tentative) evaluation on what city-level minimum wages do. The weight of evidence suggests that city mandates (especially in larger cities) have been successful in raising wages for the bottom quartile of the wage distribution, with limited impact on employment prospects for low-wage workers. But the evidence base is still limited, and for this reason we identify some key areas where further research can be particularly helpful. I]

\section{Some Basic Facts}

The first city-level minimum wage in the United States was instituted in 1993 in Washington, DC. However, city-level minimum wages remained a rather rare phenomenon until about seven years ago. To be sure, there were some isolated attempts and even some successes starting at the turn of the century. In 2002, New Orleans attempted to raise the minimum wage by $\$ 1$ above the federal standard when a majority of voters supported it on a ballot initiative, but the state of

\footnotetext{
${ }^{1}$ While we mainly focus here on US evidence, city or local minimum wages are also present in other countries. There are 15 countries (besides the US) with some type of geographical differentiation in minimum wages: Bangladesh, China, India, Indonesia, Japan, Pakistan, Philippines, Vietnam, Portugal, Switzerland, Burundi, Canada, Malawi, Tanzania, and Kenya. Among these, Bangladesh, China, India, Indonesia, Burundi, and Kenya have city-level minimum wages. Pakistan has a different minimum wage in Islamabad Capital Territory, which is federal territory (like DC). Portugal has different minimum wage for (archipelagos) Azores and Madeira. Malawi's minimum wage differentiates between urban versus rural. Tanzania's minimum wage differentiates between mainland and (archipelago) Zanzibar. The rest of countries have state/province variation. Switzerland has two cantons (Jura and Neuchatel) with minimum wages and the canton of Geneva just passed a law to introduce one. Therefore, around 6-10 countries have city minimum wages depending on the definition (Tijdens and van Klaveren 2019).
} 
Louisiana barred local governments from setting the minimum wage. In 2004, San Francisco and Santa Fe successfully introduced local minimum wage ordinances. Both of these cities were located in states that already had minimum wages above the federal level, but these cities decided to go further. In San Francisco's case, the policy came out of a ballot initiative backed by more than 60 percent of the voters.

By 2010, only these three cities had city-level minimum wage. Yet ten years later, city-level minimum wages had spread to 42 major cities, including New York, Chicago, Los Angeles, Seattle, Denver, and Minneapolis. Today, city-level minimum wage policies cover almost 8 percent of the US workforce. However, these 42 cities with their own minimum wages are all located in only nine states, showing significant regional concentration. Moreover, of these 42 cities, 29 are located in California, and in turn, 24 of these are cities in the San Francisco Bay Area.

This shift to cities as a focus of efforts to raise the minimum wage is not the result of major changes in the legal environment. In general, cities can pass laws on specific issues for which they have explicit permission from the state, but they can also pass laws within a broader category of issues, as long as they are not specifically preempted by state or federal laws. Instead, the recent increase in city-level minimum wages seems to reflect two developments: first, the federal minimum wage has been stagnant over the past decade, and second, even when state legislatures have enacted a higher minimum wage, it has often been below the level desired in certain high-wage, high cost-of-living cities (Rapoport 2016). These two developments pushed minimum wage advocates to move their efforts to the local level. Beginning in 2012, a coalition of unions-especially the Service Employees International Union-and progressive advocates helped launch the "Fight for Fifteen" movement. In November 2012, groups of workers from many fast food chains walked off their jobs in New York City, demanding a minimum of $\$ 15$ per hour and other workplace rights. The momentum spread nationally. In 2014, SeaTac and then Seattle successfully passed ordinances mandating city-wide minimums. Other cities followed, building on these early successes and from having a national-level organizing infrastructure in place.

However, it is important to remember that states ultimately have the power to decide whether cities can institute their own minimum wage policies (Briffault 2018). As mentioned earlier, preemption legislation in Louisiana barred New Orleans from setting its own minimum wage in 2002. As another example, St. Louis, Missouri, approved a minimum wage increase in 2015, which went into effect in 2017 following nearly two years of litigation. However, the state quickly passed a new law preempting cities in Missouri from setting minimum wages. As a consequence, the higher St. Louis minimum wage was in effect for only three months. By 2018, 28 US states had preemption legislations in place, banning city-level minimum wages within their jurisdiction (EPI 2018). [? $^{2}$

\footnotetext{
${ }^{2}$ One of these is Oregon, which does not allow city-level minimum wages; however, in 2016, the Oregon legislature established a three-tiered minimum wage plan. The highest minimum wage tier established
} 
There are also some counties with minimum wages above the state level, although these counties typically either contain or adjoin a city with a higher minimum wage. Examples include Cook County in Illinois, which encompasses the city of Chicago; Montgomery County and Prince George's County in Maryland, which adjoin Washington, DC; Los Angeles County in California, which includes the city of Los Angeles; and Bernalillo County in New Mexico, which includes the city of Albuquerque. The state of New York also set a separate minimum wage for "downstate" counties near New York City (Nassau, Suffolk, and Westchester counties), and Oregon has introduced a three-tiered minimum wage where the wage floor varies across rural, non-rural, and Portland metro counties. In this paper, we will focus specifically on city-level minimum wages. However, we suspect that these county-level minimum wage changes are likely to have similar implications.

In most cases, city-level minimum wages cover nearly all low-wage workers working within the city limits. A notable exception is the city of SeaTac in Washington state, where only workers in the hospitality and transportation sector are bound by the law (the law notably excludes the SeaTac international airport, the largest employer in the city). There are also some cities with separate minimum wages for tipped workers (as in New York City). Finally, in many cases the local ordinance allows for small businesses to set somewhat lower wages.

The top panel of Table 1 shows the 10 largest cities with local minimum wage ordinances. The three largest US cities-New York, Los Angeles, and Chicago-all had city-level minimum wages in place as of January 2020. Among the top ten largest cities with their own minimum wages, four have a minimum wage that is at least $\$ 15$ per hour and two other large cities are scheduled to pass the $\$ 15$ per hour threshold by 2022 . Currently, the highest state-level minimum wage is in Washington state at $\$ 13.50$ per hour; in contrast, six of the ten largest cities with minimums have levels exceeding $\$ 13.50$ per hour. At the same time, large cities also tend to be areas where wages are generally higher for everyone, and this should be taken into account when assessing the level of the minimum wage.

To better gauge the bite of the city minimum wages, we calculate the median wage for each city using the latest wave of the American Community Survey and look at the ratio of the minimum wage to median wage- the so called Kaitz index. The (unweighted) average Kaitz index in the largest ten cities is around 0.58. This average is substantially higher than the average state-level Kaitz index, which is 0.48. This implies that the top ten largest cities introducing minimum wages went substantially further in their minimum wage policies than the average US state, even after accounting for differences in the overall wage levels.

The bottom panel of Table 1 reports the ten cities with the highest nominal minimum wages. The two highest nominal minimum wage cities-Seattle and SeaTac - are both located in Washington state, while the rest of cities that made the list are all in the San Francisco Bay Area. The top ten highest nominal minimum

a wage floor for the Portland Urban Growth Boundary. This is effectively a Portland city-level minimum wage, which we include in our analysis below. 
Table 1

\section{Some Cities with Minimum Wages}

\begin{tabular}{|c|c|c|c|c|}
\hline Cities & Population & $\begin{array}{l}\text { Minimum } \\
\text { wage } \\
\text { in } 2020\end{array}$ & $\begin{array}{l}\text { Kaitz } \\
\text { index }\end{array}$ & $\begin{array}{c}\text { Planned nominal } \\
\text { minimum wage } \\
\text { in } 2022\end{array}$ \\
\hline \multicolumn{5}{|c|}{ Panel A. Largest Population Cities with Minimum Wages above the State Level } \\
\hline 1. New York City & $8,398,748$ & 15.00 & 0.66 & 15.00 \\
\hline 2. Los Angeles & $3,990,469$ & 14.25 & 0.75 & 15.72 \\
\hline 3. Chicago & $2,705,988$ & 13.00 & 0.65 & 13.60 \\
\hline 4. San Jose & $1,030,119$ & 15.25 & 0.56 & 16.20 \\
\hline 5. San Francisco & 883,305 & 15.59 & 0.45 & 17.05 \\
\hline 6. Seattle & 744,949 & 16.39 & 0.57 & 17.19 \\
\hline 7. Denver & 716,492 & 12.85 & 0.58 & 15.87 \\
\hline 8. Washington, DC & 702,455 & 14.00 & 0.48 & 14.50 \\
\hline 9. Portland & 652,573 & 12.50 & 0.56 & 14.75 \\
\hline 10. Albuquerque & 560,234 & 9.35 & 0.55 & 9.60 \\
\hline \multicolumn{5}{|l|}{ Mean of top 10} \\
\hline Unweighted & $2,038,533$ & 13.82 & 0.58 & 14.95 \\
\hline Population weighted & & 14.33 & 0.64 & 15.04 \\
\hline \multicolumn{5}{|c|}{ Panel B. Highest City-Level Minimum Wages (Nominal Minimum Wage in 2020) } \\
\hline 1. Seattle & 744,949 & 16.39 & 0.57 & 17.19 \\
\hline 2. SeaTac* & 28,925 & 16.34 & 0.67 & 16.79 \\
\hline 3. Emeryville & 11,724 & 16.30 & 0.65 & 17.92 \\
\hline 4. Mountain View & 83,377 & 16.05 & 0.34 & 17.05 \\
\hline 5. Sunnyvale & 153,175 & 16.05 & 0.39 & 17.05 \\
\hline 6. Berkeley & 121,654 & 15.59 & 0.60 & 17.15 \\
\hline 7. San Francisco & 883,305 & 15.59 & 0.45 & 17.05 \\
\hline 8. Los Altos & 30,588 & 15.40 & 0.33 & 16.40 \\
\hline 9. Palo Alto & 66,655 & 15.40 & 0.33 & 15.85 \\
\hline 10. Santa Clara & 129,489 & 15.40 & 0.43 & 15.85 \\
\hline \multicolumn{5}{|l|}{ Mean of top 10} \\
\hline Unweighted & 225,384 & 15.85 & 0.48 & 16.83 \\
\hline Population weighted & & 15.89 & 0.49 & 16.98 \\
\hline
\end{tabular}

Note: Kaitz index is the minimum wage divided by the median wage. The median wages of all workers are calculated from the 2018 wave of the American Community Survey and are measured in 2020 dollar value.

* Minimum wage only applies to transportation and hospitality workers within SeaTac city. We report the city-level Kaitz index, where we calculate the industry share weighted average of the minimum to median wage.

wage cities are on average small (average population is around 230,000). Among the three cities that have a long tradition of minimum wages-Washington, DC, Santa Fe, San Francisco-only San Francisco is in the top ten list for cities with the highest minimum wage.

All of the cities in Panel B of Table 1 have minimum wages exceeding $\$ 15$ per hour, but these cities also have high wages, generally. As a result, in some cases the Kaitz index is rather modest: for example, the cities of Los Altos and Palo Alto in 
the San Francisco Bay Area have a Kaitz index of only 0.33-which is lower than the current Kaitz index of the federal minimum wage of 0.37 . The average Kaitz index among the top ten highest nominal minimum wage cities is 0.48 , which is the same as the average Kaitz index among the US states. This highlights that top-line nominal minimum wage numbers can provide a misleading picture of how local minimum wage policies may affect a local economy.

Table 2 summarizes the basic characteristics of all 42 cities with minimum wages as of January 2020. We calculate city-level characteristics using the 2018 American Community Survey, the most recent data available. The first two columns report statistics for cities with minimum wages. The first column shows population weighted averages for cities with less than 100,000 residents, while the second column shows the statistics for cities with more than 100,000 residents as of 2018. For comparison, the third column reports the same statistics for all US cities with at least 100,000 residents, but no city-wide minimum wages.

As expected, the nominal minimum wage is substantially higher in the cities with a local minimum wage (columns 1-2), than in the cities where only the state or the federal minimum wage applies (column 3). The difference in the nominal level of the minimum wage is substantial-around $\$ 5$ (or 50 percent). However, minimum wage cities also have around 25-75 percent larger average and median wages than other cities. As a result, the economic bite of the policy is substantially smaller than the headline nominal numbers would indicate. For smaller cities, the minimum-to-median-wage ratio is very similar to other cities without any minimum wage ( 0.50 in column 1 versus 0.52 in column 3$)$. The difference in the minimumto-median-wage ratio is sizable when we compare larger cities with and without city-wide minimums ( 0.63 in column 2 versus 0.52 in column 3 ). Furthermore, the cost of living is also much higher in minimum wage cities; using the regional price parities measured at the level of metropolitan statistical areas (MSAs), we estimate that minimum wage cities have around 16 percent higher cost of living. ${ }^{3}$ Accounting for cost of living suggests that the real value of the minimum wages in larger cities with ordinances is around 25-30 percent larger than in cities without.

Table 2 also highlights that in cities with minimum wages, the population has higher levels of education, and workers are more likely to be employed in highpaying industries such as professional services. Furthermore, and not surprisingly, cities with minimum wages are more likely to lean Democrat: in the 2016 presidential election, for example, 76 percent of the cities with their own minimum wage voted for Democrats, while in other larger cities without minimum wages, the vote share was only 55 percent. Finally, the local unemployment rate seems to be very similar between cities with and without minimums, at least for cities with a population exceeding 100,000.

\footnotetext{
${ }^{3}$ Note that the differences in cost of living are at the level of metropolitan statistical areas (MSAs) and not at the city level. That is why the differences in median and average wages are substantially larger than the differences in cost of living. This also implies that we may be underestimating the differences in cost of living across cities.
} 
Table 2

Basic Characteristics of Cities with and without Minimum Wages

\begin{tabular}{|c|c|c|c|}
\hline & \multicolumn{2}{|c|}{ Cities with a minimum wage } & \multirow{2}{*}{$\begin{array}{l}\text { Cities without a } \\
\text { minimum wage } \\
\text { Pop }>100,000 \\
(3)\end{array}$} \\
\hline & $\begin{array}{c}\text { Pop }<100,000 \\
\text { (1) }\end{array}$ & $\begin{array}{c}\text { Pop }>100,000 \\
(2)\end{array}$ & \\
\hline Number of cities & 20 & 22 & 249 \\
\hline Population (in thousands) & 55.2 & $1,034.4$ & 266.9 \\
\hline Nominal minimum wage in 2020 & 14.57 & 14.27 & 9.44 \\
\hline Planned minimum wage by 2022 & 15.71 & 15.07 & \\
\hline Mean wage & 42.31 & 31.42 & 24.58 \\
\hline Median wage & 31.26 & 22.47 & 18.04 \\
\hline Cost of living index (RPP) & 122.9 & 117.1 & 100.2 \\
\hline Minimum wage to mean wage & 0.36 & 0.45 & 0.38 \\
\hline Minimum wage to median wage & 0.50 & 0.63 & 0.52 \\
\hline Share Democrats & 0.73 & 0.76 & 0.55 \\
\hline College share & 0.47 & 0.38 & 0.30 \\
\hline Unemployment rate & 3.84 & 5.61 & 5.45 \\
\hline \multicolumn{4}{|l|}{ Industry shares: } \\
\hline Restaurants & 0.06 & 0.07 & 0.08 \\
\hline Retail & 0.09 & 0.09 & 0.11 \\
\hline Manufacturing & 0.09 & 0.06 & 0.08 \\
\hline Construction & 0.05 & 0.05 & 0.06 \\
\hline Health and social care & 0.12 & 0.14 & 0.13 \\
\hline Professional services & 0.15 & 0.11 & 0.07 \\
\hline
\end{tabular}

Note: Own calculations based on the 2018 American Community Survey. Cost of living index is the MSA level Regional Price Parity (RPP) measured in 2017. The share of Democrats in the 2016 presidential election is obtained from McGovern (2016). Each row (except the one on population) reports population weighted averages.

City-level minimum wages are above state-level minimum wages, but the cities with higher minimum wages also tend to have median wages above the state level. Figure 1 shows the distribution of the Kaitz index (ratio of minimum to median wage) for cities with minimum wages as well as the comparable distribution of state-level minimums. For the states, we only consider minimum wages when they are above the federal level. Many cities (shown by the blue line) went beyond the highest state-level Kaitz: they have higher levels of minimum wages even after differences in the median wage across locations are taken into account. On the other hand, there are many high-wage cities where the Kaitz index is quite low even with the higher nominal minimum wages. The figure shows that the Kaitz index is more dispersed for cities than for states.

If we exclude the cities in the San Francisco Bay Area with their high levels of median wages (as shown in Table 1 above), then dispersion in the city-level Kaitz indices is more comparable to the state-level one, though the average value of the Kaitz index is considerably higher in cities. Notably, the Kaitz index exceeds 0.65 in a substantial portion of cities, which it essentially never does at the state level. 
Figure 1

\section{Distribution of Kaitz Index for US Cities and States}

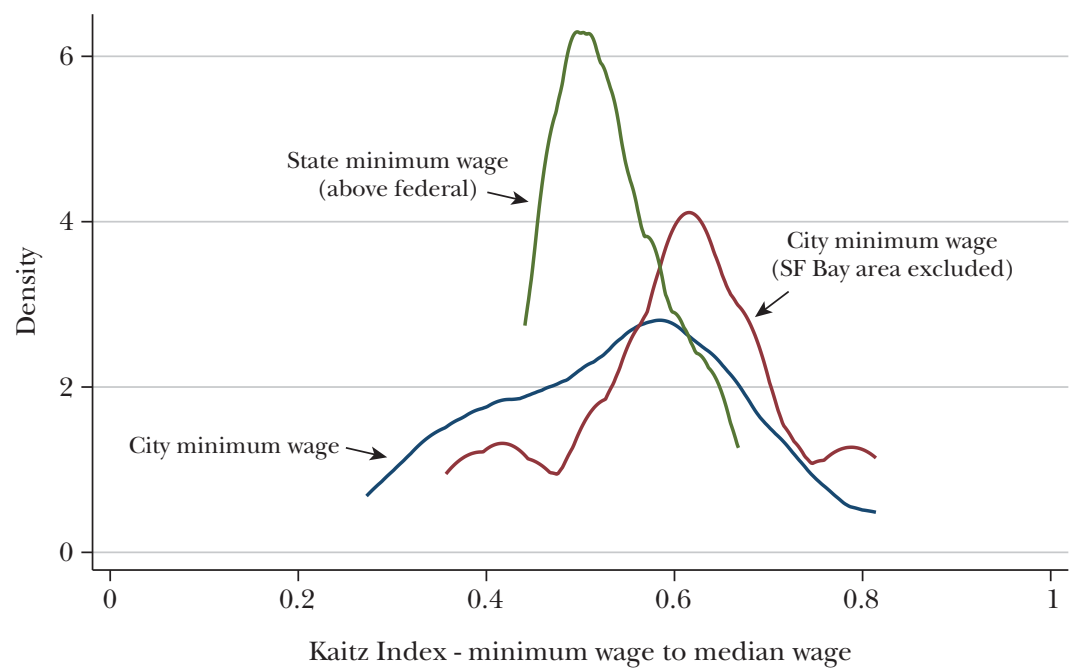

Note: The figure shows the distribution of the Kaitz index (minimum wage to median wage) for cities with minimum wages (blue and red line) and for all US states where a minimum wage above the federal one applied (green line).

To summarize, cities passing local minimum wages are typically large, with higher overall wages and cost of living. However, even after accounting for these differences, the city-wide minimum wages appear to have pushed the wage standards to be more binding than they would have from state-level policies alone.

\section{Arguments Concerning City-Level Minimum Wages}

The prevalence of city minimum wages naturally raises the question: is the growing variation in local-level minimum wages desirable? Here, we review some of the main arguments concerning minimum wages in general and consider how they apply in the context of city-level minimum wages. To do so, we assess the tradeoffs that emerge for any place-based policies (Kline and Moretti 2014). In the next section, we consider the empirical evidence for these arguments.

First, one of the oldest arguments for a minimum wage is that someone who works full-time should be able to afford the basic cost of living. However, there are large differences in costs of living across the United States (Albouy 2009). As Table 2 showed, the cities that have enacted city-wide minimum wages had, on average, a 17 percent higher cost of living as measured by the regional price parity index (at the level of metropolitan statistical areas) than other cities. A local-level minimum wage can be adjusted to take into account that workers with the same nominal wage are substantially "poorer" in locations with high costs of living. 
Second, local variation in minimum wages may serve to redistribute resources from higher-income consumers to lower-wage workers. A body of empirical studies suggests that minimum wages are passed on to consumers via higher output prices (Lemos 2008; MaCurdy 2015; Harasztosi and Lindner 2019). Because most minimum wage workers are employed in local non-tradable sectors (like restaurants or retail stores), this redistribution mainly takes place among local consumers and local minimum wage workers. As shown in Table 2, cities with minimum wages have a larger share of high-educated workers, a larger share of workforce in the professional services sector, and therefore a higher-income consumer base. In these types of cities, redistribution from local high-income consumers to local low-wage workers may be more desirable..$^{4}$

Third, another justification for minimum wages in general is that if employers have market power in the labor market, and they create a wedge between the marginal product of labor and wages, then minimum wages can potentially push wages and employment closer to the competitive equilibrium. However, the level of employer market power varies by local areas. Azar, Marinescu, and Steinbaum (2019) find that labor market concentration in the general merchandise sector varies considerably across locations and that the employment response to the minimum wages is linked to this variation.

Fourth, the minimum wage may shift the composition of local jobs. Harasztosi and Lindner (2019) and Cengiz et al. (2019) document considerable negative effects of state-level or country-level minimum wages on jobs in the tradable sector. Aaronson and Phelan (2019) find a drop in cognitive routine occupations after minimum wage hikes, while Lordan and Neumark (2018) document a drop in automatable jobs. However, in practice, such considerations do not seem to play a major role in the current context of city-level minimum wages. As shown in Table 2, the share of non-tradable sectors such as restaurants and retail or the share of tradable jobs such as manufacturing are similar in cities with and without minimum wages.

Fifth, a central concern expressed about the minimum wage is that it could reduce employment, either by causing employers to reduce the number of employees or by causing them to move out of the jurisdiction where the higher minimum wage applies. These employment and wage responses for localized minimum wage changes may differ from state or federal-level ones. After all, city boundaries are more porous than state boundaries. Businesses may simply move a few miles away to avoid minimum wage changes. Workers may seek better employment opportunities by changing their commuting patterns. In general, given the density of highways in commuting zones, labor mobility is much greater across cities than across states. As a result, it is important to assess the effect of the minimum wage directly on both employment and business reallocation across city boundaries. However, it is also important to consider whether a reallocation of businesses and

\footnotetext{
${ }^{4}$ Diamond (2016) shows that high-skilled workers do not just get higher wage premium in some cities, but they also enjoy higher amenities. This would provide an additional reason to redistribute resources from high-skilled workers to lower-skilled ones in those cities.
} 
jobs from some high-wage cities to outside their boundaries is necessarily bad from the public perspective (Albouy 2009). If a higher minimum wage does, indeed, lead to reallocation, the creation of new jobs outside of the urban core may help relatively disadvantaged areas outside city limits.

Finally, variation in minimum wages across cities can better reflect the preferences of citizens (Tiebout 1956). Residents of some cities may prefer higher minimum wages even if the policy is accompanied by various trade-offs. Table 2 highlights considerable differences between the electorates in cities with and without minimum wages in terms of supporting major political parties. Recent survey evidence by Simonovits and Payson (2020) suggests that there is a strong correlation between city-level preferences and the prevailing minimum wage.

\section{Evidence on the Impact of City-Level Minimum Wages}

There is an extensive literature studying the impact of state- and federal-level minimum wage changes, but the existing evidence on city-level minimum wage laws is limited. Here, we consider the evidence (or sometimes the lack of evidence) on the effect of city-level minimum wages.

\section{Estimates for Employment and Wages}

Three studies provide evidence on the early wave of city minimum wages. Dube, Naidu, and Reich (2007) study the effect of introducing the minimum wage in San Francisco in 2004 using two waves of a survey of restaurants and using aggregate level data from the Quarterly Census of Employment and Wages. They use a difference-in-differences approach with a variety of control groups, including firms outside of San Francisco, smaller firms unaffected by the wage mandate within San Francisco, and higher-wage firms within San Francisco. They find that the policy increased worker pay and compressed wage inequality but did not create any detectable employment loss among affected restaurants. Potter (2006) focuses on another early example of the city-level minimum wage changes: Santa Fe, New Mexico. Based primarily on comparisons with patterns in Albuquerque (about 60 miles away), Potter shows that the 65 percent increase in the minimum wage in 2004 did not had a negative impact on employment—if anything, Santa Fe actually did better than Albuquerque.

Schmitt and Rosnick (2011) study the impact of the minimum wage in three cities using firm-level administrative data from Quarterly Census of Employment and Wages: San Francisco, Santa Fe, and Washington, DC. They find that average earnings increased in San Francisco and Santa Fe, but not in Washington, DC. They, too, use a difference-in-differences approach using alternative control groups (similar to Dube, Naidu, and Reich 2007). Their estimates on employment vary considerably across specifications, making it difficult to draw a definitive conclusion. Nonetheless, the estimates are clustered around zero-suggesting that the impact on employment was likely limited. 
This early consensus on the effects of city-level minimum wage changes has been challenged recently by an influential study from Seattle. Jardim et al. (2017) study the introduction of the Seattle Minimum Wage Ordinance, which raised the minimum wage from $\$ 9.47$ to $\$ 13$ per hour in 2016 . The study makes an important improvement relative to existing evidence as it utilizes high-quality administrative data on hourly wages. The paper documents a dramatic drop in the number of jobs below $\$ 25$ per hour in Seattle relative to the other areas in Washington state. Their point estimates on employment elasticity with respect to own wage (in a competitive model, this is the elasticity of labor demand) is -2.18 . Such an elasticity is outside of the range of existing estimates in the literature exploiting state- or country-level variation in the minimum wage (see Figure $4 \mathrm{~B}$ of Dube 2019) and suggests that the policy did considerable harm to low-wage workers in Seattle.

The Seattle study received considerable attention. Jardim et al. (2017) use a credible empirical strategy that created a synthetic control for Seattle from other cities in Washington and combined it with a unique administrative data on hourly wages. Nevertheless, certain features of the Seattle experiment should lead us to a cautious interpretation of the findings. First, it turned out that the Seattle labor market evolved quite differently than the areas in the comparison group around the time of the introduction of the local ordinance, with a substantial increase in the number of jobs and wages, especially at the top of the wage distribution in Seattle. Because it is unlikely that the minimum wage has a substantial impact on jobs at the top of the wage distribution, ${ }^{5}$ such divergence between Seattle and the comparison group suggests that other shocks also affected the Seattle labor market around the policy change. Indeed, the "Seattle boom" might have shifted the whole wage distribution in a way that led low-wage jobs to disappear at the same time as more high-wage jobs were created. While the authors are careful in constructing a control group, given the generally greater wage growth in major cities during this period, it may just not be feasible to construct a counterfactual using places in Washington state outside of Seattle (which is the data the authors are using).

Furthermore, in a follow-up paper, Jardim et al. (2018) examine the employment trajectories of workers with jobs before the introduction of the minimum wage. The employment estimates for that subgroup are substantially lower: the implied employment elasticity with respect to own wage is 0.03 , and the confidence intervals rule out even moderate-sized disemployment effects. ${ }^{6}$ While these estimates do not

\footnotetext{
${ }^{5}$ The neoclassical model does predict that low-skilled workers will be replaced by high-skilled ones in response to the minimum wage. However, because the share of minimum wage workers in total production is low, we expect limited effects on the upper tail employment under reasonable values of labor-labor substitution (for details, see Cengiz et al. 2019, Appendix B). Therefore, the overall increase in employment (relative to the synthetic control) suggests that other major shocks around the time of the reform played an important role.

${ }^{6}$ Jardim et al. (2018) report separate estimates on the effect of the minimum wage on total hours and on employment. We focus here on the head count estimates as those are more comparable to the existing literature. Jardim et al. (2018) find a significant drop in total hours, which amplifies the negative consequences of minimum wage changes. We discuss the change-in-hours results below.
} 
take into account the potential for a drop in new entrants to the labor market, they are also less affected by the overall shift of the wage distribution. As a result, it is unclear whether these estimates are biased upward or downward.

In a study on the impact of city-level minimum wages on employment in the restaurant sector in six large cities, Allegretto et al. (2018) use data from the Quarterly Census of Employment and Wages aggregated at the county-by-industry level. While their analysis is based on less rich data than the Seattle study by Jardim et al. (2017), they can use all counties without minimum wages to find the best comparison group. Given that the cities with minimum wages are quite unique, it may be important to go outside of a given state (like Washington) to find a better comparison group. Allegretto et al. (2018) find considerable increases in wages and disemployment effects that are modest and statistically insignificant. Interestingly, Allegretto et al. also study the employment changes in Seattle and find no indication for negative disemployment effects in the restaurant sector.7]

Table 3 summarizes some key estimates in the literature on the impact of the city-level minimum wages on own wages and employment. Because it is hard to interpret the findings on employment in the absence of any wage responses to the policy, we only report estimates with statistically significant effects of the minimum wage on wages. Column 5 reports the employment elasticity with respect to own wage.

Table 3 highlights that the employment elasticity estimates are centered around zero, which suggests that city-level minimum wages have no discernible effect on employment. Out of the eleven estimates, seven have positive point estimates and four have negative sign for employment. Only two point estimates have an own-wage employment elasticity less than minus one, thereby implying that the total wage bill collected by low-wage workers falls after the policy change as a result of job losses. Nevertheless, individual estimates are quite noisy even if we consider the 90 percent confidence intervals. Only two estimates can rule out that the employment is unaffected by the policy: Jardim et al. (2017) aggregate-level one finds a statistically significant negative employment effect, while Allegretto et al. (2018) in Oakland finds a statistically significant positive estimate on employment. Six estimates in the literature can rule out large negative employment effects (employment elasticity is less than -1) and three estimates can rule out medium-sized negative employment responses (employment elasticity is less than -0.4 ).

Overall, the evidence on city-level minimum wages is consistent with the growing body of evidence suggesting that moderate levels of minimum wage increases have a relatively small employment effect on the affected workers (Cengiz et al. 2019; Belman and Wolfson 2014). At the same time, it is important to point out that there

\footnotetext{
${ }^{7}$ Jardim et al. (2017) also provide separate estimates for restaurants. Similarly to Allegretto et al. (2018), they confirm that the overall number of jobs did not fall in the restaurant sector. At the same time, they find some drop in employment for jobs below $\$ 25$ per hour, which they interpret as substitution away from low-wage workers. However, Nadler et al. (2019) show that small industry-wide employment elasticities are inconsistent with highly elastic labor demand for low-wage workers, given plausible elasticities of substitution across skill groups.
} 
Table 3

\section{Existing Estimates on City-level Minimum Wage Changes}

\begin{tabular}{|c|c|c|c|c|}
\hline Paper & City & Wage & Employment & $\begin{array}{l}\text { Own-Wage } \\
\text { Elasticity }\end{array}$ \\
\hline \multirow[t]{5}{*}{$\begin{array}{l}\text { Allegretto et al. } \\
\text { (2018)_restaurants }\end{array}$} & Average of 6 cities & $\begin{array}{c}0.02 \\
{[0.01,0.03]}\end{array}$ & $\begin{array}{c}-0.01 \\
{[-0.02,0.01]}\end{array}$ & $\begin{array}{c}-0.23 \\
{[-0.78,0.32]}\end{array}$ \\
\hline & Oakland & $\begin{array}{c}0.10 \\
{[0.06,0.14]}\end{array}$ & $\begin{array}{c}0.07 \\
{[0.03,0.11]}\end{array}$ & $\begin{array}{c}0.71 \\
{[0.20,1.22]}\end{array}$ \\
\hline & San Francisco & $\begin{array}{c}0.06 \\
{[0.04,0.09]}\end{array}$ & $\begin{array}{c}0.01 \\
{[-0.05,0.07]}\end{array}$ & $\begin{array}{c}0.14 \\
{[-0.83,1.11]}\end{array}$ \\
\hline & San Jose & $\begin{array}{c}0.11 \\
{[0.06,0.15]}\end{array}$ & $\begin{array}{c}0.00 \\
{[-0.06,0.06]}\end{array}$ & $\begin{array}{c}-0.02 \\
{[-0.57,0.53]}\end{array}$ \\
\hline & Seattle & $\begin{array}{c}0.04 \\
{[0.02,0.07]}\end{array}$ & $\begin{array}{c}0.01 \\
{[-0.05,0.07]}\end{array}$ & $\begin{array}{c}0.20 \\
{[-1.16,1.57]}\end{array}$ \\
\hline $\begin{array}{l}\text { Dube, Naidu, and Reich } \\
(2007) \text {-restaurants }\end{array}$ & San Francisco & $\begin{array}{c}0.14 \\
{[0.06,0.22]}\end{array}$ & $\begin{array}{c}0.04 \\
{[-0.12,0.2]}\end{array}$ & $\begin{array}{c}0.29 \\
{[-0.34,0.91]}\end{array}$ \\
\hline \multirow[t]{2}{*}{$\begin{array}{l}\text { Jardim et al. ( } 2017 \text {, } \\
\text { 2018)_jobs below } \$ 19\end{array}$} & Seattle, worker level & $\begin{array}{c}0.15 \\
{[0.14,0.17]}\end{array}$ & $\begin{array}{c}0.01 \\
{[-0.01,0.02]}\end{array}$ & $\begin{array}{c}0.03 \\
{[-0.04,0.11]}\end{array}$ \\
\hline & Seattle, aggregate level & $\begin{array}{c}0.03 \\
{[0.03,0.03]}\end{array}$ & $\begin{array}{c}-0.07 \\
{[-0.14,-0.01]}\end{array}$ & $\begin{array}{c}-2.18 \\
{[-4.14,-0.22]}\end{array}$ \\
\hline $\begin{array}{l}\text { Moe, Parrott, and Lathrop } \\
\text { (2019)—full service } \\
\text { restaurants }\end{array}$ & New York City & $\begin{array}{c}0.09 \\
{[0.03,0.16]}\end{array}$ & $\begin{array}{c}0.03 \\
{[-0.16,0.22]}\end{array}$ & $\begin{array}{c}0.29 \\
{[-1.74,2.32]}\end{array}$ \\
\hline \multirow[t]{2}{*}{$\begin{array}{l}\text { Schmitt and Rosnick } \\
\text { (2011)_fast food }\end{array}$} & San Francisco & $\begin{array}{c}0.10 \\
{[0.05,0.14]}\end{array}$ & $\begin{array}{c}0.00 \\
{[-0.33,0.34]}\end{array}$ & $\begin{array}{c}0.03 \\
{[-3.45,3.5]}\end{array}$ \\
\hline & Santa Fe & $\begin{array}{c}0.07 \\
{[0.02,0.12]}\end{array}$ & $\begin{array}{c}-0.08 \\
{[-0.29,0.13]}\end{array}$ & $\begin{array}{c}-1.20 \\
{[-4.36,1.96]}\end{array}$ \\
\hline
\end{tabular}

Note: We report the estimated impact of city-level minimum wages on wages (column 3), on employment (column 4), and on employment elasticity with respect to own wage - the labor demand elasticity in the competitive model (column 5). We only report estimates where positive wage effects have been detected in the data. When the elasticity with respect to own wage was not directly reported (Allegretto et al. 2018; Dube, Naidu, and Reich 2007, Jardim et al. 2017, 2018), we calculated the elasticity by dividing the employment effect with the wage effect. The corresponding standard errors were calculated by using the delta method. All estimates report the 90 percent confidence intervals. We calculate the standard errors in Moe, Parrott, and Lathrop (2019) using Randomization Inference.

is sizable uncertainty around the existing estimates. There is plenty of room for additional research to glean important information on this question.

\section{Overall Impact of City-Wide Minimum Wages}

Almost all studies on the impact of city-level minimum wage changes focus on a particular city and a particular minimum wage hike. However, inferences based on any particular case study is inherently difficult. Furthermore, estimates based on 
any single experiment may be easily contaminated by other shocks, as is possibly the case for the Seattle study.

The Allegretto et al. (2018) study mentioned previously is an exception to the single-city approach, because it reports event-study estimates exploiting six prominent minimum wage hikes. But many more city-level minimum wage changes could be used for identification. In fact, studies on the combined evaluation of city-level minimum wage changes are noticeably missing. This is in stark contrast to the literature on state-level minimum wage changes, which moved some years ago from a case-by-case analysis (as in the work of Card and Krueger 1994) to combined evaluation of many state-level minimum wage shocks (for example, Neumark and Wascher 1992; Dube, Lester, and Reich 2010; Cengiz et al. 2019). Moreover, Allegretto et al. (2018) only look at restaurants, and therefore, cannot fully resolve the concerns raised by Jardim et al. (2017).

Here we make a first effort at filling this hole in the literature by providing an overall assessment of the city-level minimum wage changes instituted as of 2018 . We have three specific objectives. First, we wish to evaluate the full set of major cities instituting or raising the city-wide minimums during the recent period. Second, we wish to consider the overall impact of these policies on low-wage jobs in the spirit of Cengiz et al. (2019) and Jardim et al. (2017), as opposed to focusing on particular sectors or groups. Third, having shown how selective the minimum wage cities are, we wish to address concerns about invalid counterfactuals by comparing these cities with other large cities with similar characteristics that did not raise their minimum pay standard.

For this exercise, we use the American Community Survey between 2012 and 2018 that has data on wages and employment at the city level. This dataset provides the geographic granularity needed to home in on specific cities, something not feasible with other publicly available datasets. We start with a sample of all cities with a population of at least 100,000 in 2018 (last year of our sample). This leaves us with 21 cities with minimum wage changes.

We estimate the following regression using samples from the American Community Survey from 2012, 2013, 2017 and 2018:

$$
y_{c t}=\beta_{0}+\beta_{1}\left(\text { Treat }_{c} \times \text { Post }_{t}\right)+\beta_{2}\left(X_{c, 2012} \times \text { Post }_{t}\right)+\mu_{c}+\tau_{t}+e_{c t} .
$$

The left-hand variable is the main outcome of interest-for us, either wage percentile or employment-at city $c$ at time $t$. Treat $t_{c}$ is a dummy variable for cities with minimum wage as of 2018. Post $t_{t}$ is a dummy for years 2017 and 2018. Finally, $\mu_{c}$ are city fixed effects (thus adjusting for time-invariant unobserved heterogeneity) and $\tau_{t}$ controls for year effects.

Of course, a central issue in the minimum wage literature arises because jurisdictions which enact a higher minimum wage are not chosen exogenously or at random. Given that we expect differences between cities that introduced minimum wages and those that did not, we control for the interaction of a dummy for Post with a set of 2012 covariates $X_{c, 2012}$ on cost of living, employment to population 
ratio, average wage, the $10 \mathrm{th}, 25 \mathrm{th}, 50 \mathrm{th}, 75 \mathrm{th}$, and 90 th wage percentiles, shares of employment below wage cutoffs $(\$ 15, \$ 20, \$ 25, \$ 30, \$ 50)$, and sectoral shares measured at the one-digit level. As we will see below, controlling for pretreatment city characteristics produces much more sensible results on the upper tail of the wage distribution, which can be considered a key falsification test for both wage and employment effects (as discussed in Autor, Manning and Smith 2016; Cengiz et al. 2019). We weight the regressions by population of the city and cluster the standard errors at the state level.

Figure 2 studies the contribution of city minimum wages to inequality in spirit of Autor, Manning, and Smith (2016). We report the estimated $\beta_{1}$ coefficient from the regression where the outcome variable is various percentiles of income measured in log hourly wages. We compute hourly wages as (annual) salary income divided by hours per week times number of weeks worked. ${ }^{8}$

Panel A in Figure 2 shows the estimates without controlling for the covariates $X_{c, 2012}$ in the regression. As expected, there is a clear increase in wages at the bottom of the wage distribution in cities with minimum wages relative to the cities without minimum wages. However, wages also increase significantly for all percentiles (including the very top) throughout the wage distribution. Because minimum wages are unlikely to have much effect on wages at the very top, the no-controls results here highlight that comparing cities with and without minimum wages can lead to misleading results. Instead, a plausible interpretation would be that cities experiencing wage growth across the income distribution may be more likely to enact their own minimum wage laws.

The second panel in Figure 2 controls for baseline differences in cities with a minimum wage, interacted with a post-treatment dummy. The results with controls show a clear change at the bottom of the wage distribution that fades out around the 30 th percentile of the wage distribution. Such spillover effects are broadly similar to the estimates in Autor, Manning, and Smith (2016) who find a similar pattern for state-level minimum wage changes.

The evidence is consistent with a belief that the city-level minimum wages affect workers' pay at the bottom of the wage distribution and have compressed wage inequality. However, the magnitude seems modest. If we estimate the same regression using the log of the minimum wage as an outcome variable, we find that the minimum wages increased by 23 percent (with a standard error of 1.6 percent) more in cities with a minimum wage throughout this period. This increase is substantially larger than the roughly 4 percent increase in wages at the bottom of the distribution. This discrepancy likely reflects that the increasing tightness across all labor markets during this time period additionally led to wage growth even in cities that did not increase the minimum wage. This limited how binding these minimum

\footnotetext{
${ }^{8}$ The specific variables that we use from the American Community Survey are: "Salary income in the last 12 months"; "Usual hours worked per week in the last 12 months"; "Weeks worked during the last 12 months." Given that the weeks variable is coded using intervals (in six categories), we take the midpoint of each interval in all categories but the last one ( 50 to 52 weeks) where we assign a value of 52 .
} 


\section{Figure 2}

\section{City-Level Minimum Wages and Inequality}
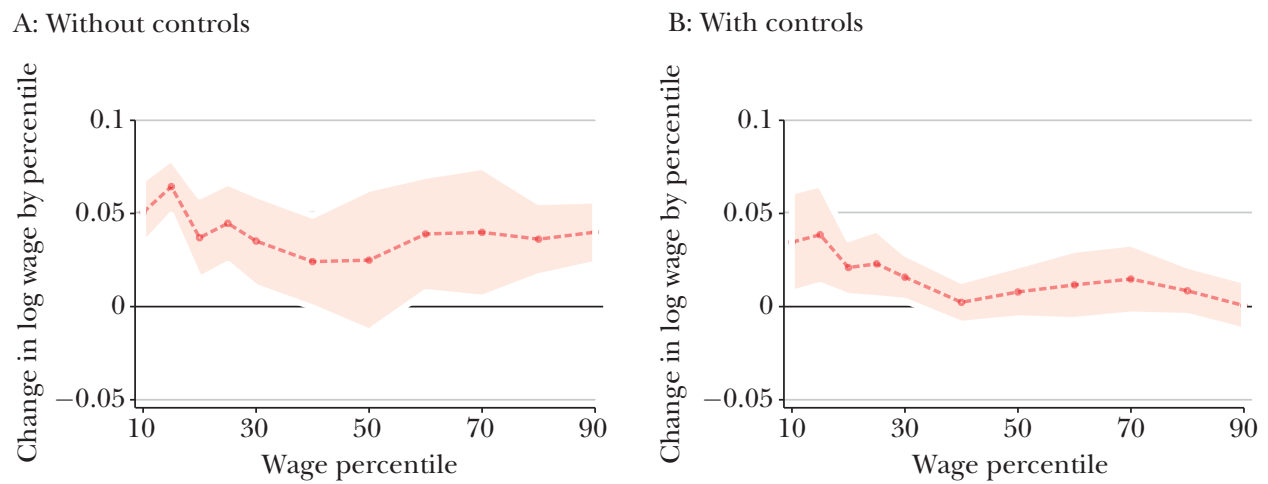

Note: This figure shows the change in log wages for each wage percentile from our regression analysis (see the equation in the text) exploiting 21 city-level minimum wage changes between 2012 and 2018. The shadowed area shows, for each percentile, the 95 percent confidence intervals around the estimate. Panel A shows the estimates with time- and city-fixed effects but without controlling for the set of 2012 covariates interacted with the post dummy. Panel B controls for 2012 values of cost of living, employment to population ratio, average wage, wage percentiles, shares of employment below wage cutoffs, and 1-digit level sectoral shares. Results are weighted by the population size of the city. For detailed regression results, see the online Appendix available at the $J E P$ website with this paper.

wage changes were, and thereby, attenuated the inequality-reducing impact of the city minimum wage policies.

Did cities adopting a minimum wage experience both wage growth and weaker job growth at the bottom of the wage distribution? We assess the employment effects of the minimum wage with the distributional approach developed in Cengiz et al. (2019), which divides the wage distribution into a set of "bins." By studying the effect of the minimum wage on employment for each wage "bin" separately, we can calculate the missing number of jobs at the bottom of the wage distribution and compare it to the excess number of jobs higher up in the wage distribution. ${ }^{\overline{9}}$ This approach also allows us to study the changes in the upper part of the wage distribution. Large changes there would suggest that the estimates for the impact of the city-level minimum wages are potentially contaminated by other shocks.

Panel A in Figure 3 shows the bin-by-bin employment estimates from our earlier regression equation without controls. There is a clear drop in employment at the bottom of the wage distribution (jobs under $\$ 10$ ) in cities with minimum wage, which is in line with a binding minimum wage policy. In addition, there is no apparent increase in the number of jobs higher up in the wage distribution, except

\footnotetext{
${ }^{9}$ This approach is also closely related to the Jardim et al. (2017) aggregate estimate, where they consider changes in employment below thresholds (for example, $\$ 19$ per hour). This allows us to consider how similar the findings are when we pool across multiple minimum wage events and also when we use other large cities as controls (instead of rural and suburban Washington state).
} 


\section{Figure 3}

\section{City-Level Minimum Wages and Employment Changes}

A: Without controls

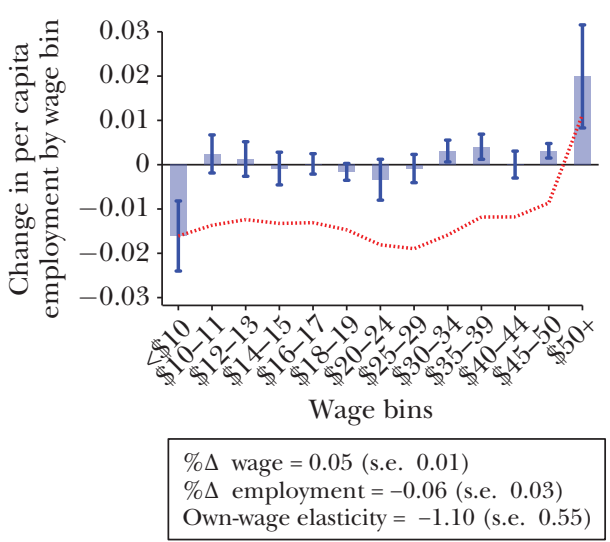

B: With controls

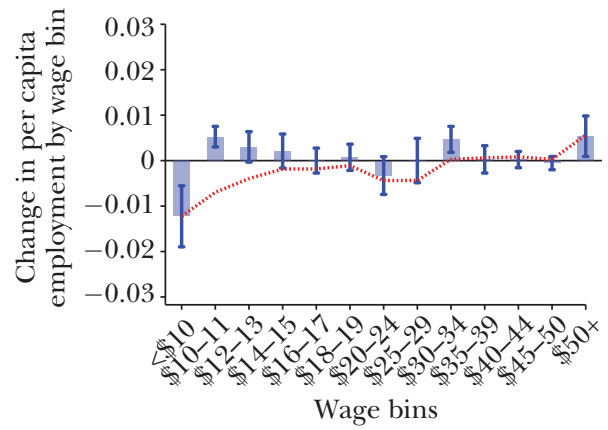

$\% \Delta$ wage $=0.04$ (s.e. 0.01$)$

$\% \Delta$ employment $=-0.00$ (s.e. 0.01$)$

Own-wage elasticity $=-0.12$ (s.e. 0.38$)$

Note: The figure shows the bin-by-bin employment changes from our regression analysis (based on the equation in the text) exploiting 21 city-level minimum wage changes between 2012 and 2018. The blue bars show, for each wage bin, the estimated average employment change in that bin relative to the total employment in the city in 2012. The error bars show the 95 percent confidence intervals. The red line shows the running sum of employment changes up to the wage bin to which it corresponds. Panel A shows the estimates with time- and city-fixed effects but without controlling for the set of 2012 covariates interacted with the post dummy. Panel B controls for 2012 values of cost of living, employment to population ratio, average wage, wage percentiles, shares of employment below wage cutoffs, and 1-digit level sectoral shares. Results are weighted by the population size of the city. For detailed regression results, see the online Appendix available at the $J E P$ website with this paper.

at the very top where there is a large increase in the number of jobs. The missing number of jobs under $\$ 10$ per hour only recovers once jobs above $\$ 50$ per hour are incorporated. In fact, overall employment increased in cities with minimum wage, even if at the bottom of the wage distribution there are large job losses. When we consider jobs up to $\$ 20$ per hour, Panel A suggests that wages for this group of workers rose by around 5 percent while their employment fell by around 6 percent. The implied disemployment is quite pronounced: the estimated own-wage employment elasticity of -1.10 is statistically significant at the 95 percent confidence level. ${ }^{10}$

\footnotetext{
${ }^{10}$ We calculate the percentage change in employment and wages as in Cengiz et al. (2019). In particular, the percentage change in affected employment is the change in employment below $\$ 19$ (relative to pretreatment total employment) divided by the (sample average) share of workforce below the new minimum wage. To calculate the wage changes, we use equation 2 in Cengiz et al. (2019); see the online Appendix for details. It is worth mentioning that Jardim et al. (2017) calculate the employment elasticity somewhat differently: they divide the percentage change in employment below $\$ 19$ per hour by the percentage change in average wage below $\$ 19$ per hour. This approach dilutes the wage effects, since the change in wages of the workers close to the $\$ 13$ per hour minimum wage is compared to higher
} 
However, the story is very different when we control for the differences in baseline characteristics across cities. In Panel B, Figure 3 shows that once we control for observable baseline differences, the dramatic change in the upper part of the wage distribution disappears. We continue to find that cities with minimum wages have some missing jobs under $\$ 10$ per hour, but once we control for the baseline characteristics, we find that excess number of jobs emerge at jobs between $\$ 11$ and $\$ 19$ per hour. The upper part of the wage distribution is more or less stable at higher parts of the wage distribution, which is consistent with a relatively low impact of the minimum wage at that part of the wage distribution. Our estimates suggest that affected workers experienced a 4 percent additional wage gain, but the employment changes were negligible. The implied employment elasticity with respect to wage is -0.12 . The 90 percent confidence interval rules out own-wage employment elasticities more negative than -0.75 (including the point estimate of -1.1 from the specification without controls).

These estimates are quite similar to the overall minimum wage literature to date. For example, the median own-wage employment elasticity in the literature is around -0.17 , while it is around -0.04 when restricting attention to broad-based groups (Dube 2019). At the same time, the confidence interval here also rules out some other prominent negative estimates from the minimum wage literature. Importantly, the aggregate own-wage employment elasticity of -2.18 in the Jardim et al. (2017) study of Seattle lies far outside of our confidence interval.

Indeed, the differences between the two panels in Figure 3 can help shed light on the controversy surrounding the Seattle minimum wage studies. The findings in Panel A are strikingly similar to the aggregate-level findings in Jardim et al. (2020, see Appendix Figure 7). In Seattle, too, there was an apparent drop in jobs below the new minimum wage and those jobs did not recover if only jobs below a certain threshold (say, $\$ 20, \$ 25$, or $\$ 30$ per hour) are considered. Nevertheless, similar to our results here, Jardim et al. (2020) find an overall increase in jobs in Seattle that mainly came from an unusual job creation above $\$ 50$ per hour. These employment patterns are observed even though Jardim et al. (2020) are careful to construct a synthetic control; however, as we pointed out before, all of their control areas come from within Washington state. The raw-versus-control comparisons in Figures 2 and 3 document that the cities with minimum wages are often unique in terms of economic structure, costs of living, and wage and employment growth trends, and in general, it might be difficult to find comparable cities within a state with similar characteristics.

The analysis here shows that the inclusion of the full set of controls produces much better-behaved findings when it comes to the upper tail falsification tests, while also suggesting relatively modest impacts on affected employment. However, the results here suggest that the parallel trends assumption appears to hold only

wage workers earning just below $\$ 20$ per hour. As a result, the Jardim et al. (2017) estimates overstate the employment elasticity. If we calculate the employment elasticity using their approach, we get -1.65 (with a standard error of 0.84 ), qualitatively similar to their estimate for Seattle of -2.18. 
conditionally on covariates, highlighting the systematic differences between cities with and without minimum wages. This is different from the findings from statelevel policies, where state-level estimates are not sensitive to exclusion of additional controls for time-varying heterogeneity (Cengiz et al. 2019). This naturally raises the question: how sensitive are these results to the particular set of controls included here? In the online Appendix, we show that the estimates are very similar when controlling for a small number of city characteristics chosen using a data-driven procedure, specifically the double-selection post-LASSO proposed by Belloni, Chernozhukov, and Hansen (2014). In particular-and as discussed above-treated cities had a much higher share of workers in professional services in the pretreatment period and not accounting for this particular difference seems to impart a large amount of bias.

As always in the minimum-wage literature, the key to assessing the effects of the minimum wage is to find a credible comparison group, and the selectivity of cities makes this a more difficult challenge than at the state level. However, the existing evidence, including the results presented here, does not indicate that citywide minimum wages differ substantially from state-level ones in terms of wage and employment responses. Besides the effect of city-level minimum wages on inequality, wages, and employment, it is worth considering evidence on other aspects of these minimum wage policies-which we do in the remainder of this section.

\section{Geographic Reallocation}

Businesses may be able to avoid city-level minimum wages by shifting their production outside city boundaries. Such a shift in employment would create wage and employment spillovers in neighboring cities and counties. However, we are not aware of any studies that directly assess the presence of such spillover effects in the city minimum wage context.

If the effect of the minimum wage spills over to its own suburbs, but not to nearby cities, we would expect that the wage effects are smaller in the own-suburb estimates and the employment effects are larger than the estimates on nearby cities. There is no such tendency found in Schmitt and Rosnick (2011). Furthermore, the fact that much of the existing estimates of the effect of a city-level minimum wage on employment are centered around zero suggests that business reallocation must be limited. However, more precise documentation by future researchers on when such spillovers occur and how large they are would be useful.

\section{Firm Entry and Exit}

At least in theory, city-level minimum wage policies could affect the rates of firm entry and exit. The existing evidence on firm's closure is inconclusive. Dube, Naidu, and Reich (2007) do not detect any increase in the rate of business closure. On the other hand, Jardim and van Inwegen (2019) find that the Seattle Minimum Wage Ordinance accelerated exit of firms with a higher share of low-wage jobs. Luca and Luca (2019) exploit Yelp data to show that the exit rate of firms increased in response to the minimum wage, especially for those firms providing low quality 
services (measured by low Yelp ratings on the website). Such increase in business exit rate might reflect within-city reallocation of workers from lower-paying, lowerquality firms to higher-paying, higher-quality ones-a channel that is found to be important in responding to the introduction of the minimum wage in Germany (Dustmann et al. 2020).

The evidence on firm entry in the context of city-level minimum wages is even more limited. Jardim and van Inwegen (2019) find no effect on city-level minimum wage policies on the overall rate of business entry, though they document a change in the composition of the entering firms towards less labor-intensive businesses.

\section{Hours Worked and Other Benefits}

Even if a city-level minimum wage policy does not affect the overall number of jobs, it might potentially affect hours worked or other employment benefits. In their analysis of the Seattle data, Jardim et al. (2017) find a substantial decrease in hours worked for jobs below $\$ 19$ per hour. As discussed above, it is unclear whether the drop in hours reflects the shift of the wage distribution discussed above or the genuine effect of the minimum wage. Looking at earlier evidence, and contrary to the findings in Seattle, Dube, Naidu and Reich (2007) find (if anything) a positive effect of a city-level minimum wage on hours worked.

The discrepancy between these two studies may be explained, at least in part, by the different data sources used in the analysis. Jardim et al. (2017) exploit administrative data on hours, while Dube, Naidu, and Reich (2007) rely on survey data. It is possible that some firms avoid compliance to the minimum wage by underreporting hours, a practice that was found to be important in Germany (Caliendo et al. 2018). Such underreporting might affect the results based on administrative data sets but not the results based on survey data. Dube, Naidu, and Reich (2007) also study whether the impact of a pay increase resulting from a higher city-level minimum wage is offset by cutting non-cash benefits. They find no indication for cutting health insurance benefits and document an increase in the proportion of workers receiving tips.

\section{Output Prices}

A key channel of absorption of minimum wages is passing prices through to consumers. However, if the city-level minimum wage only applies to a subset of an integrated metro-area-wide product market, price pass-through may be difficult. On the other hand, if the demand for products is tightly linked to locations within the city itself, it may be possible for prices to exhibit sharp differences near city boundaries. Additionally, as we have argued, cities raising minimum wages tend to have residents with higher incomes and these consumers may be more willing and able to absorb an increase in prices of minimum wage intensive services and goods.

The empirical findings on this front are varied. Dube, Naidu, and Reich (2007) find that output prices increase especially for the fast food sector, particularly when comparing firms within versus outside of San Francisco. On the other hand, Jardim and Van Inwegen (2019) study the effect of the minimum wage on output prices 
in Seattle and find somewhat inconclusive evidence. Perhaps the most persuasive evidence on price responses comes from Allegretto and Reich (2018) who study the impact of the San Jose minimum wage change on Internet-based restaurant menus inside and outside of the city boundaries. Allegretto and Reich (2018) find clear and positive price effects in response to the minimum wage that are consistent with the large body of evidence on state-level minimum wage changes. What is particularly telling is that they document a sharp drop on output prices just a mile from the San Jose city boundary. Therefore, otherwise similar restaurants operating within a few miles of each other-but facing differential shocks to labor costs-seem able to set different consumer prices. This suggests a very sharp segmentation of certain markets, even when the boundary is as porous as it is between San Jose and adjacent smaller cities like Sunnyvale and Milpitas. Overall, the sharp reduction in prices indicates that spillover effects of a city-wide minimum wage policy are limited even in the context of the San Francisco Bay Area with highly interlinked cites.

\section{Worker Turnover}

Minimum wage policies can affect labor market flows. In models of a frictional labor market where employers have some wage-setting power, a higher minimum wage can lead to a reduction in worker turnover at the bottom of the wage distribution: essentially, a higher minimum wage improves the relative quality of the lowest-paying jobs and increases retention (Portugal and Cardoso 2006; Dube, Lester, and Reich 2016). In turn, the decrease in turnover can lead to potential cost savings that can help to explain how a higher minimum wage is absorbed by employers without a substantial drop in employment.

Such a mechanism seems to play some role in the context of city-level minimum wages. Dube, Naidu, and Reich (2007) find an increase in worker tenure for a typical worker in the context of the San Francisco minimum wage increase, though they do not detect a reduction in overall separation rate. Jardim et al. (2018) find statistically significant reductions in separations following the Seattle minimum wage changes. Overall, the evidence from city minimum wages offers a qualified similarity to the broader literature suggesting reduced worker turnover is likely to be one of the channels of adjustment.

\section{Conclusion}

A growing number of cities have recently instituted their own minimum wages above the state or the federal one recently. Local variation in minimum wages tailors the policy more closely to the local economic and political environment. At the same time, city-level minimum wages might be more distortionary, because relocating businesses outside of city boundaries may be easier than relocating outside of the state or the country. While the literature on city-level minimum wages is still at an early stage, existing evidence does not indicate that the employment and wage responses differ substantially from the responses to state-level changes. Overall, the 
weight of the evidence is consistent with these policies having moderately raised wages at the bottom without a large change in employment probabilities. Much of the adjustment seems to have been similar to state- and federal-level increases: through higher consumer prices, which in this case is mostly borne by middle- and higher-income consumers, and through some reductions in labor turnover costs. Considerable uncertainty surrounds some of these estimates, and more research is needed.

We expect a growing number of case studies will emerge soon concerning the impact of the policy in large cities such as Los Angeles and Minneapolis. Nevertheless, the literature can also benefit from exploiting combined analysis of the city-level minimum wage changes.

The new minimum wage literature began with studying the impact of a single change in the minimum wage in New Jersey-comparing changes in fast food employment in that state with changes in the neighboring state of Pennsylvania (Card and Krueger 1994). After the recent rapid expansion in the number of citylevel minimum wages, economic research now has the ability to exploit hundreds of minimum wage increases. Data limitations pose some real challenges, but we see much value in exploiting more than single events to identify the effect of the policy. Our own findings presented in this paper provides an initial attempt at such a synthetic analysis; we hope to see much more. One additional point merits a mention: while use of state-specific administrative data can be of great help if there are credible control groups present within the state, the costs of relying on one state may exceed the benefits if proper control groups are not available. Furthermore, there is scope to learn from analyses using widely available public-use data, like the Quarterly Census of Employment and Wages or the American Community Survey. This is similar to the conclusion reached in Cengiz et al. (2019), who show that wage data from the Current Population Survey has comparable accuracy in many cases as hourly wage data from administrative sources. We think a similar lesson may apply to the city-wide context as well, at least for some questions.

Finally, surprisingly little research has been devoted to some important aspects of city-wide minimum wages. Direct evidence on business reallocation across city boundaries seems potentially important to assess the key trade-off emerging from introducing local variation in the policy. It also would be valuable to study the welfare implications arising from the potential reallocation of business from the core of a city to the more disadvantaged areas. Additional evidence on rental and housing prices also would help us to understand the welfare implications of minimum wage policies. We hope these gaps in the literature will be filled in the next wave of research on city-level minimum wages.

- We thank Pat Kline, Enrico Moretti, and Michael Reich for useful suggestions. We are grateful to Jon Piqueras for outstanding research assistance. Lindner acknowledges financial support from the Economic and Social Research Council (new investigator grant, ES/ T008474/1) and from the European Research Council (ERC) under the European Union's 
Horizon 2020 research and innovation programme (grant agreement Number 949995). Dube acknowledges financial support from the Russell Sage Foundation. Dube and Lindner acknowledge financial support from the Arnold Foundation.

\section{References}

Aaronson, Daniel, and Brian J. Phelan. 2019. "Wage Shocks and the Technological Substitution of LowWage Jobs.” The Economic Journal 129 (617): 1-34.

Albouy, David. 2009. "The Unequal Geographic Burden of Federal Taxation." Journal of Political Economy 117 (4): 635-67.

Allegretto, Sylvia, Anna Godoey, Carl Nadler, and Michael Reich. 2018. The New Wave of Local Minimum Wage Policies: Evidence from Six Cities. Berkely, CA: Center on Wage and Employment Dynamics.

Allegretto, Sylvia, and Michael Reich. 2018. "Are Local Minimum Wages Absorbed by Price Increases? Estimates from Internet-Based Restaurant Menus.” ILR Review 71 (1): 35-63.

Autor, David H., Alan Manning, and Christopher L. Smith. 2016. "The Contribution of the Minimum Wage to US Wage Inequality Over Three Decades: A Reassessment.” American Economic Journal: Applied Economics 8 (1): 58-99.

Azar, José, Ioana Marinescu, and Marshall Steinbaum. 2019. "Measuring Labor Market Power Two Ways." AEA Papers and Proceedings 109: 317-21.

Belloni, Alexandre, Victor Chernozhukov, and Christian Hansen. 2014. "High-Dimensional Methods and Inference on Structural and Treatment Effects." Journal of Economic Perspectives 28 (2): 29-50.

Belman, Dale, and Paul J. Wolfson. 2014. What Does the Minimum Wage Do? Kalamazoo, MI: WE Upjohn Institute.

Briffault, Richard. 2018. "The Challenge of the New Preemption." Columbia Public Law Research Paper 14-580.

Caliendo, Marco, Alexandra Fedorets, Malte Preuss, Carsten Schröder, and Linda Wittbrodt. 2018. "The Short-Run Employment Effects of the German Minimum Wage Reform." Labour Economics 53: 46-62.

Card, David, and Alan B. Krueger. 1994. "Minimum Wages and Employment: A Case Study of the FastFood Industry in New Jersey and Pennsylvania.” The American Economic Review 84 (4): 772-93.

Cengiz, Doruk, Arindrajit Dube, Attila Lindner, and Ben Zipperer. 2019. "The Effect of Minimum Wages On Low-Wage Jobs.” The Quarterly Journal of Economics 134 (3): 1405-54.

Diamond, Rebecca. 2016. "The Determinants and Welfare Implications of US Workers' Diverging Location Choices by Skill: 1980-2000.” American Economic Review 106 (3): 479-524.

Dube, Arindrajit. 2019. Impacts of Minimum Wages: Review of the International Evidence. London: HM Treasury.

Dube, Arindrajit, T. William Lester, and Michael Reich. 2010. "Minimum Wage Effects across State Borders: Estimates Using Contiguous Counties." The Review of Economics and Statistics 92 (4): 945-64.

Dube, Arindrajit, T. William Lester, and Michael Reich. 2016."Minimum Wage Shocks, Employment Flows, and Labor Market Frictions." Journal of Labor Economics 34 (3): 663-704.

Dube, Arindrajit, Suresh Naidu, and Michael Reich. 2007. "The Economic Effects of a Citywide Minimum Wage." ILR Review 60 (4): 522-43.

Dustmann, Christian, Attila Lindner, Uta Schönberg, Matthias Umkehrer, and Philipp Vom Berge. 2020. "Reallocation Effects of the Minimum Wage: Evidence from Germany." Unpublished.

Economic Policy Institute (EPI). 2018. "Worker Rights Preemption in The U.S. A Map of the Campaign to Suppress Worker Rights in The States." https://www.epi.org/preemption-map/.

Fajgelbaum, Pablo D, Eduardo Morales, Juan Carlos Suárez Serrato, and Owen Zidar. 2019. "State Taxes 
and Spatial Misallocation". The Review of Economic Studies 86, No. 1: 333-376.

Harasztosi, Peter, and Attila Lindner. 2019. "Who Pays for the Minimum Wage?" American Economic Review 109 (8): 2693-2727.

Kline, Patrick, and Enrico Moretti. 2014. "People, Places, and Public Policy: Some Simple Welfare Economics of Local Economic Development Programs.” Annual Review of Economics 6: 629-62.

Jardim, Ekaterina, Mark C. Long, Robert Plotnick, Emma Van Inwegen, Jacob Vigdor, and Hilary Wething. 2017. "Minimum Wage Increases, Wages, and Low-Wage Employment: Evidence from Seattle.” NBER Working Paper 23532.

Jardim, Ekaterina, Mark C. Long, Robert Plotnick, Emma Van Inwegen, Jacob Vigdor, and Hilary Wething. 2018. "Minimum Wage Increases and Individual Employment Trajectories." NBER Working Paper 25182.

Jardim, Ekaterina, Mark C. Long, Robert Plotnick, Emma van Inwegen, Jacob Vigdor, and Hilary Wething. 2020. "Minimum Wage Increases and Low-Wage Employment: Evidence from Seattle." Unpublished.

Jardim, Ekaterina, and Emma Van Inwegen. 2019. "Payroll, Revenue, and Labor Demand Effects of the Minimum Wage." Upjohn Institute Working Paper 19-298.

Lemos, Sara. 2008. "A Survey of the Effects of the Minimum Wage on Prices." Journal of Economic Surveys 22 (1): 187-212.

Lordan, Grace, and David Neumark. 2018. "People versus Machines: The Impact of Minimum Wages on Automatable Jobs." Labour Economics 52: 40-53.

Luca, Dara Lee, and Michael Luca. 2019. "Survival of the Fittest: The Impact of the Minimum Wage on Firm Exit.” NBER Working Paper 25806.

MaCurdy, Thomas. 2015. "How Effective Is the Minimum Wage at Supporting the Poor?" Journal of Political Economy 123 (2): 497-545.

McGovern Tony. 2016. "United States General Election Presidential Results by County from 2008 to 2016.” https://github.com/tonmcg/US_County_Level_Election_Results_08-16 (accessed May 1, 2020).

Moe, Lina, James Parrott, and Yannet Lathrop. 2019. New York City’s \$15 Minimum Wage and Restaurant Employment and Earnings. New York: New York City Affairs at the New School and the National Employment Law Project.

Nadler, Carl, Sylvia A. Allegretto, Anna Godøy, and Michael Reich. 2019. "Are Local Minimum Wages Too High?” Institute for Research on Labor and Employment Working Paper 102-19.

Neumark, David, and William Wascher. 1992. "Employment Effects of Minimum and Subminimum Wages: Panel Data on State Minimum Wage Laws.” ILR Review 46 (1): 55-81.

Portugal, Pedro, and Ana Rute Cardoso. 2006. "Disentangling the Minimum Wage Puzzle: An Analysis of Worker Accessions and Separations.” Journal of the European Economic Association 4 (5): 988-1013.

Potter, Nicholas. 2006. Measuring the Employment Impacts of the Living Wage Ordinance Santa Fe, New Mexico. Albuquerque: University of New Mexico, Bureau of Business and Economic Research.

Rapoport, Abby. 2016. "Blue Cities Battle Red States." The American Prospect, August 22. https://prospect. org/economy/blue-cities-battle-red-states/.

Schmitt, John, and David Rosnick. 2011. The Wage and Employment Impact of Minimum-Wage Laws in Three Cities. Washington, DC: Center for Economic and Policy Research.

Simonovits, Gábor, and Julia Payson. 2020. "Locally Controlled Minimum Wages Are No Closer to Public Preferences." Unpublished.

Tiebout, Charles M. 1956. "A Pure Theory of Local Expenditures.” Journal of Political Economy 64 (5): 416-24.

Tijdens, Kae, and Maarten van Klaveren. 2019. "Understanding the Drivers of Minimum Wage-Setting: An Analysis of 146 countries." Paper presented at the ILO's 6th RDW Conference in Geneva, July 8-10, 2019. 